\title{
The Outlooks of Using the European Populists Experience in the Development of Political Parties in the Post-Soviet Space
}

\author{
Amiantova Irina S. ${ }^{1} \&$ Mikhaylova Natalia V. ${ }^{1}$ \\ ${ }^{1}$ RUDN University, Russia \\ Correspondence: Amiantova Irina S., RUDN University, Russia. E-mail: politnayka@mail.ru
}

Received: September 7, 2019

Accepted: September 20, 2019 Online Published: November 28, 2019

doi:10.5539/jpl.v12n4p31

URL: https://doi.org/10.5539/jpl.v12n4p31

\begin{abstract}
The study features prospects for the implementation of European experience in the development of political parties in the post-Soviet states. The methodology of the study is based on a combination of descriptive analysis with case study. The article shed light on the fact that the experience of European populists can be successfully employed in the post-Soviet countries, but to a limited degree. First, a favorable environment for its application is present in states where there is no vertical power structure that help elites to integrate, and establishment groups have a substantial resource potential and can politically challenge respective opponents' control over key political institutions. Accordingly, it can be employed at the regional level, in depressed areas that are not essential to the stability of the political system and have long been governed ineffectively. Bearing in mind ways and means of the European populists, it can be concluded that in order to avoid sanctions their experience can be successfully applied by those groups within the non-mainstream opposition that are exploited by the factions of the ruling establishment to organize attacks on competitors.
\end{abstract}

Keywords: elections, Europe, political parties, populism, the post-soviet countries

\section{Introduction}

Populism is gaining momentum in the EU electoral field hence the surge of academic interest to the subject. Recently academic circles saw large number of publications on "success stories" of populist parties in Europe (Zabelin \& Vlasova,2015; Maslova, 2017; Narochnitskaya,2017). Many scholars tried to concentrate mainly on the country-specific cases (Nesterov \& Dzhayani, 2016; Rakhmanov, 2016; Stepanov, 2017). In the pan-European scale the electoral populism has been the study subject in the works of T. L. Rovinskaya (Rovinskaya , 2015) and V. Ya. Shveister (Shveister, 2016).

Even though the subject has been thoroughly studied, academic circles tend to overlook such an important aspect as the prospects for the spread of "new populism" in the post-Soviet countries. Meanwhile, the electoral developments of recent years show significant degree of success of politicians and parties mirroring the means of European populists. Success N.V. Pashinian and the party "Elk" in Armenia, the unexpectedly high rating of V. A. Zelensky in the presidential race in Ukraine, the victory of V. O. Konovalov in the gubernatorial elections in Khakassia - these milestones are tethered. The sociological data indirectly evidence high chances of euro-populist methods being successfully implemented in the post-Soviet countries. For example, as the Single Voting Day 2018 in Russia showed, the intentions declared by the respondents significantly differ from the real results of the elections. Similar trends have already been traced in Europe on the eve of the "populist wave" rise (Ponomarev, 2019).

The study purpose is to determine the prospects for the implementation of European experience in the development of political parties in the post-Soviet states.

\section{Research Methodology}

The methodology of the study is based on a combination of descriptive analysis with case study. While writing this article, the authors used also traditional scientific methods: analysis, synthesis, comparison. The selected methods turn out to be helpful in reaching the research goal. 


\section{Findings and Discussion}

\subsection{Political Parties: Definition, Characteristics, Key Functions}

In modern science does not hold a generally accepted definition of the term "political party" (Avtonomow, 2005). Russian authors alone have offered more than 200 variants of interpretation of this concept. Often, the party means a voluntary self-governing association of citizens, created and based on their incentive for the joint implementation of goals and objectives, promoting their views on the development of society (Zaslavsky, 2005).

However, experts maintain similar characteristics of a traditional political party.

Political parties differ from other public associations based on the following:

- the presence of a professional administrative apparatus, ensuring the long-term performance of the organization;

- existence of a network of sustainable field offices with links to national leadership;

- the objective to obtain, exercise and retain political power, or to influence its bearers;

- a desire to gain the support of wider population, the degree of which is determined by elections;

- having a certain ideology, worldview and system of values.

The key functions of parties as public institutions are as follows:

- $\quad$ struggle for power;

- representation of social groups;

- integration of social groups whose interests they protect;

- $\quad$ policy formulation and implementation;

- political recruitment, i.e. formation of the ruling elite (Avtonomow, 2005).

The modern parties began to form around the 1850 s with their main focus on social conflicts. In the process of confrontation, the interested parties were separated, and their ideologies were formed accordingly. Initially, the conflict could have been other than of ideological nature. However, the parties, while seeking public support, developed doctrines that are close to the interests of the general public. Support of the population through voting turned into a resource of influence. The party leadership could use it to defend its personal and small-group interests. At the same time, it was obliged to protect the interests of its voters. Other patterns of political behavior threatened with loss of their electoral support. Its preservation also called for a close relationship between political practice and party ideology (Avtonomow, 2005).

For participants of the conflict parties were a tool of upholding of interests in the political arena. Traditional parties could rely on bedrock voters. As a rule, their voters came from one social class, whose interests were best represented by a party (Zaslavsky, 2005). In industrialized countries a strong correlation between the voting patterns of different constituencies and social status were established. The poor had tendency to support social democrats and communists, and the middle and upper classes voted for the liberal and conservative parties respectively (Zaslavsky, 2005).

The 1850s saw the structure of society in developed countries start to get more sophisticated. New parties and public organizations that were mediums for local group interests began to appear. An example of a party of this kind is the Free Democratic Party of Germany that focused on the protection of the interests of the scientific and technical intelligentsia and employed citizens. Large traditional parties have begun to compete for the right to represent various social groups. The blurring of social boundaries between parties has led to the destruction of ideological differences between them. Mass surveys conducted in 2002 showed that two-thirds of the French no longer feel the difference in the approach and ideological attitudes of socialists and Republicans (Novozenova,2004). This has eroded the traditional social electoral bank of the parties. At the same time, their representation function has also been reduced. The practice of contractual relations between parties and candidates for the exchange of resources has been expanded. The ideological orientation of the new members has lost its importance with the priority given to capital both material and symbolic to ensure the success of the elections. In countries where there is a bipartisan (or two-bloc) system, the crisis of representation is particularly acute. The dominant parties, aware of the stability of their own status, entrenched in themselves, tend to ignore opinion of the electorate. Some voters either lost interest in ideology or shifted to new political parties, including politically marginalized ones (Zaslavsky, 2005).

The Spain party system can be seen as manifestation of crisis trends. Since the $1985 \mathrm{~s}$ the political field of the 
country was dominated by two parties: The People's Party (NP) and The Spanish Socialist Workers Party (PSOE). They controlled (until 2011) about $80-85 \%$ of the electorate bank. The loses of one party automatically means the gain of the other. The proportion of voters supporting them remained roughly the same. The party leadership is vested with broad powers. The parties are organized in a hierarchical manner and have a system reminiscing of chiefdom. The key decisions are made by the leader of the party and narrow circle of trustees. The leader can appoint and dismiss party functionaries, to convene a congress, control the capital of the organization. Open discussions in both parties are not allowed. The policy of their leadership has no clear reference to ideology: socialists support neoliberal reforms while the NP regularly exercises left-wing rhetoric (Henkin, 2015).

Thus, major political parties in Europe have now ceased to perform several basic functions. They do not represent the interests of the groups that make up their traditional social base. The parties have ceased to consolidate the social groups whose interests they formally meant to protect. Representatives of the social base of parties are often not involved in the process of formation of the political elite. The political course is developed and implemented without considering the opinion of the electorate. This goes along with the rejection of a clear orientation to a certain ideology.

\subsection{Political Parties: Crisis Trends and Phenomenon of Populism}

Changing the structure of society creates new conflicts within it. However, the parties ignore them. Their leaders claim to support all the conflicting groups. The refusal of the parties from the full performance of representative functions is the result of this. This creates the basis for the formation of new ideological and party groups. This trend is reinforced by the political passivity of traditional parties. They often demonstrate unwillingness or inability to resolve the problems facing society. (Among them we can mention the growth of illegal migration, the decline in living standards, the strengthening of organized crime, the growth of the terrorist threat, etc.) Ignoring these threats does not put down the conflicts they generate. That naturally accelerates the formation of "anti-system" parties (Henkin, 2015).

The preservation of existing conflicts in society eliminates attempts to build "conflict-free" ideologies. At the same time political practice only increases the growth of distrust of the electorate for "their" parties. The attempt to build an ideology that does not put any form of social conflict at their foundation also calls into question the stability of parties. This was clearly confirmed by the primaries of the Socialists and the Republicans, passed in France in 2017. For the first time, the leading parties were represented by candidates who represented not the majority, but ideology. The consequence of this was the aggravation of the split within both parties (Narochnitskaya, 2017).

Traditional parties react aggressively to the attempts of new political associations to increase their influence. This is manifested through the coordination of actions against new parties. In Sweden, the two dominant parties: the liberal conservatives and the social democrats have formed an unspoken alliance against the "non-mainstream." (The far-right party Swedish Democrats is considered as one) (Shveitser, 2016). During the local elections in France in 2015 republicans and socialists united against the National Front (Note 1). In Germany, the CDU and the SPD coordinated their actions to prevent representatives of the Alternative for Germany from entering the executive branch of government (Shveitser, 2016).

Thus, the evolution of the party system of European countries in recent decades has led to a crisis of the traditional system of representation. Large parties seek to express the interests of all social groups. Ideological differences between them were nullified. They have ceased to express the position of traditional electorate. "Old" parties ignore conflicts within society. The opposing sides are interested in the emergence of forces capable of representing their interests.

The weakness of traditional parties to respond to the financial crisis of 2008-2009, their inability to solve citizens issues, contributed to their decline in popularity among the population. There was growing unrest, which, in turn, led to the popularity of "anti-parties".

The new party attracted:

- protest-minded electorate, whose position is ignored by the authorities;

- individuals who have not previously participated in the elections due to lack of alternative;

- supporters and members of traditional parties dissatisfied with the rejection of the original ideology;

- representatives of the social strata most affected by the socio-economic reforms of $1990-2010$. And to a large extent, they are opponents of globalization and neoliberalism. 
The proponents of the new parties are the following social groups:

- residents of large cities, middle class, affected by the economic crisis;

- owners of small and medium-sized businesses;

- employees with secondary education;

- professors, highly qualified specialists - people from the sphere of service and education;

- young and middle-aged people;

- representatives of the ethnic majority (Stepanov, 2017).

Party ideologies are based on the principles of populism, social ecology, anti-Islamism, anti-immigration and Euroscepticism. This set of principles is not universal, so that party can accept some principles and deny others. There is a growing popularity of nationalism and conservatism. The use of popular ideas in their agenda has largely helped the "protest parties" to succeed. Initially, the parties received support in those regions where such topics had been of utmost relevance (Stepanov, 2017).

The new parties undergo evolution in different ways and through different means both in the direction of radicalization of demands and in the more moderate direction. Yet the common feature is that their leadership seeks to expand the electoral bank. It is this need that explains the changes in the attitudes and slogans of the parties. Changes in the demands are not accompanied by a loss of ideological overtones ("Podemos": as a University Professor ruined bipartisan Spain, 2016).

Many new parties emerged from social movements. They either originated in the university environment (young educated activists), or were organized by an authoritative, popular personality (experienced, established leader). This kind of "anti-party" mainly arose on the wave of protests with the direct participation of their founders in mass demonstrations.

The movements organized by media personalities tried to declare themselves publicly. Parties created by young activists initially recruited supporters in certain circles, rather than engaged in self-promotion.

The aim of the new parties was initially to participate in "big politics" and influence it from the inside from a position of criticism of the government. Even the Green Party, which initially did not consider itself as a political party, actively tried to influence state policy in the field of ecology and energy .

Most parties follow a form of political organization called "direct democracy". Therefore, many "anti-parties" are organized on the principles of horizontal coordination, so they are characterized by a decentralized structure (Nesterov \& Dzhayani, 2016).

The new European parties are aimed at the strata of the population affected by the socio-economic transformations. Their electorate wants not so much stability as radical changes for the better soon. The parties promise to "restart" the political system, returning the society to the pre-crisis state. Fears for their own future are being spread among voters for electoral gain .

The content of their electoral campaigns comes down to the guarantees of security and preservation of their traditional way of life. Parties position themselves as defenders of basic western values - personal freedom, democracy and progress, and anti-globalism.

Their opponents are labeled as "enemies of democratic rule", a closed "caste". Traditional parties are considered agents of influence of transnational corporations and global influence groups. The new party emphasize their "antielitism and anti-system approach" ("Podemos": as a University Professor ruined bipartisan Spain, 2016).

They claim to be the only political force that openly and honestly discusses current issues. The only center of political power that does not practice deception and promotes the "people's" agenda.

In order to promote the campaign to the masses, they adopt grassroots approach. Parties discard the official dress code. The appearance of politicians corresponds to the daily appearance of voters. They reject the official and business style of speech. Campaign materials are cleared of signs of a high position in the political hierarchy. The image of the candidate and the party is designed to identify with the ordinary voter. Popular subjects of mass culture are used to create APM (Pogorelskaya, 2015).

Promotion is conducted through the framework of mass protests. The party uses high-profile trials to promote itself. Campaign materials are often given a shocking and humorous character. Riotous conduct and distribution of propaganda products are carried out with elements of carnivalization (dressing up, using symbolic elements of the wardrobe, etc.). Internet resources are widely used for propaganda purposes. On such basis party TV 
channels with a wide variety of programs are created. The organization, created by leaders of public opinion, often rely on the TV. Young activists mainly promote their parties through the use of social networks (Rovinskaya, 2015).

The new parties' growth in popularity is caused by a set of factors. Their leaders are not afraid to propose solutions to the controversial problems that traditional parties try to avoid. The political practice of the new associations is consistent with the principles and values they adhere to. The parties build their agenda in accordance with the opinion of voters. Even in cases when it is assessed as marginal in the public space. (At the same time, the parties avoid elements of extremist ideologies: racism, anti-Semitism, etc.) Hence voters begin to perceive the party as a real expression of their own interests. This gives people the reason to belief that they can really influence the actions of the authorities. As a result, the motivation of voters of new parties to participate in electoral processes is growing. The ideology of the party is clearly political, and an abstract voter can easily distinguish it among the centrist associations that slightly differ from each other (Shveitser, 2016).

Parties can increase their electorate at the expense of supporters of different ideologies that adhere to similar values. Agreement on key issues outweighs, in this case, existing differences.

In their political programs, the parties stand as non-mainstream and anti-elitist. This highlights their "popular" character. The basic values of party ideologies are democracy, justice and patriotism. The latter is often intertwined with nationalism. The patriotic agenda is used to form a sense of threat from external enemies:

- transnational business structures;

- supranational institutions of power (European Commission, European Parliament, etc.);

- international terrorist cells;

- migrants who do not want to accept the European way of life (Shveitser, 2016).

The image of the external enemy played along with the ideas already existing in mass consciousness. The problems were tied to the actions of the external enemy and the traditional parties cooperating with it. The voter is offered an attractive image of the future, which can be reached without any sacrifices according to their party promises. All this combined further strengthens support for new parties.

The new European parties are regarded by most experts as populist. The term "populism" has no clear, conventional definition. It is used in both positive and negative contexts.

Populism, in a negative limelight, is interpreted as the achievement of political goals by offering unenforceable policies and sweeping criticism of the ruling establishment. At the same time, there are positive interpretations of populism. This concept is interpreted as a notion for giving the policy a new character, more focused on the opinion and interests of the masses of the population, seeking to return the democratic system to its roots (Kynev, 2017).

Within the framework of political strategy populism can be defined as a methodology of influencing public opinion through regular appeal to the interests and rights of a population and imitation of the "average" pattern of behavior, building an image based on positive stereotypes inherent in citizens, demonstrating the lack of ties with the elites, promoting the "people's agenda", simplifying the existing socio-political issues and promising to painlessly and quickly resolve the contradictions prevalent in society. All these features can be easily found in the political practices of the new European parties (Kynev, 2017).

\section{3 "Instrumental Populism" in the Post-Soviet Space}

"Instrumental populism" has long been firmly established in the political culture of the post-Soviet States. As a good example in this case we can refer to the modern-day Russia.

All political forces in Russia, without notable exceptions, promise more than they can deliver. For example, on the eve of the Duma elections of 2003, candidates from the United Russia party promised to the electorate to raise standard of living, and the Liberal Democratic Party of Russia promised the voters in a 3 years period to completely eradicate organized crime, to change the federal structure of Russia to the unitary and to write off debts for all industrial and agricultural businesses. The Yabloko party assured the electorate that in 2 years it will create 40 million high-paying jobs and will ensure transition to a fully contract-based army. The electoral bloc Rodina promised the electorate a 4-time increase in minimum wages and a doubling of welfare payments.

During the elections to the state Duma in 2016, the LDPR promised to close borders for labor migrants for 5 years, nationalize heavy industry and limit a difference in income to 10 -fold maximum. Populist methods have long been employed by high-profile politicians at federal and regional levels. The grassroots elements were 
pillars of positive image of V. V. Putin (e.g. the inclusion in the speech of colloquial, deliberately rude vocabulary) and elements inherent in the stereotypical image of "masculine leader" (the emphasis on the excellent physical form and his commitment to "musculine" sports). The Russian President Putin's Annual Call-In Program also contain a particular element of populism: in the framework of this project, the President often acts as a defender of ordinary citizens before the bureaucratic machine. It is impossible to ignore the favorite practice of many Russian governors to arrange "public scolding" for subordinates, during which the head of the region accuses high-ranking officials of neglecting the interests of the people. Andrey Vorobyev (the Governor of the Moscow region) and Sergei Morozov (the Governor of the Ulyanovsk region) both actively used this method (Efanova \& Bogapova, 2015).

Immediately obvious is the fact that the entrenchment of populism in Russian political circles testifies to the broad prospects for the introduction of the experience of new European parties in the post-Soviet space. However, the reality is, there are several obstacles that might prevent from using their methodological and ideological experience (Ponomarev,2019).

First, it should be noted that most post-Soviet States are characterized by a multi-ethnic population with cold-phase inter-ethnic conflicts. Bearing that in mind political elites strictly regulate the use of right-wing, nationalistic discourse. An attempt to use such discourse in Russia, Belarus or Kazakhstan will inevitably result in sanctions from the political leadership.

Second, the authorities of most post-Soviet States adhere to the principle of zero tolerance regarding the use of violence against law enforcement by protesters. The tactics of the "street struggle" of the Spanish Podemos or Greek SYRIZA in this case is not applicable to post-Soviet reality: the party that tried to copy mirror such tactics in most post-Soviet republics will soon be pronounced an extremist organization (Ponomarev,2019).

It is important to pay attention to the fact that no potential leaders of the populists, nor the corresponding segments of the electorate, in most cases, are not willing to be sufficiently flexible in regard to the tactics they employ. It should also be noted that in the post-Soviet space there is no social base for populist parties of a new type in the form of a large middle class (or its former representatives who have been marginalized under the influence of globalization). Similarly, there is no sacralised image of the (recent) past, no motives of industrial development and social state. The Soviet past could be a historical narrative, but this period of history in most of the former Soviet republics is purposefully demonized. The history of most of the post-Soviet republics is built more around the sacralization of the pre-revolutionary (i.e. pre-industrial) past and folk culture, etc. (Kynev,2017).

\section{Conclusions}

The experience of European populists can be successfully employed in the post-Soviet countries, but to a limited degree. First, a favorable environment for its application is present in states where there is no vertical power structure that help elites to integrate, while establishment groups have a comparable resource potential and are able to challenge each other's control over key political institutions (primarily Armenia, Ukraine, Kyrgyzstan, Georgia). Second, it can be employed at the regional level, in depressed areas that are not key to the stability of the political system as a whole and have long been governed ineffectively. Third, bearing in mind ways and means of the European populists, it can be concluded that in order to avoid sanctions their experience can be successfully applied by those groups within the non-mainstream opposition that are exploited by the factions of the ruling establishment to organize attacks on competitors and avoid respective sanctions.

\section{Acknowledgements}

The article is prepared within the support of the «RUDN University Program 5-100».

\section{References}

"Podemos": as a University Professor ruined bipartisan Spain. (2016, January 15) Retrieved April 17, 2019 from http://www.furfur.me/furfur/changes/changes/216357-podemos

Avtonomov et al. (2005). Political parties. Why you need them? Strategy of Russia,9,10. Retrieved March 7, 2019

from http://sr.fondedin.ru/new/fullnews.php?subaction=showfull\&id=1130135934\&archive=1130138106\&start_ from $=$ \&ucat $=14 \&$

Efanova, E. V., \& Bogapova, A. V. (2015). Populist rhetoric in the electoral political space of modern Russia: the regional aspect. Bulletin of the Volgograd State University, 6(36), 118-126. https://doi.org/10.15688/jvolsu4.2015.6.15 
Henkin, S. M. (2015). The Changing face of the party system in Spain. Elections and election campaigns in Europe (2014-2015). Reports of the Institute of Europe, 320, 47-57.

Kynev, A. V. (2017). Electoral populism in the Russian elections. Bulletin of public opinion. Data. Analysis. Discussions, 1-2(124), 65-81.

Maslova, E. A. (2017). Euroscepticism and populism in Italy: an example of the "Five stars" movement. Contours of global transformations: politics, economics, law, 1(10), 141-157. https://doi.org/10.23932/2542-0240-2017-10-1-141-157

Narochnitskaya, E. A. (2017). Unexpected results of the 2017 elections in France: General and special, natural and elections in France 2017: results and prospects. Reports of the Institute of Europe, 347, 11-19.

Nesterov, A. G., \& Dzhayani, M. S. (2016). Five Star Movement as Phenomenon of "Protest Party" in Italy of XXI Century. Scientific dialogue, 11(59), 290-303.

Novozenova, I. S. (2004). The national front in France. The right radical in contemporary Europe, 2, 99-124.

Pogorelskaya, S. V. (2015). Green and free: the Union 90/Green Party in search of a new identity. The Role of small parties in the party and political system of Germany. Reports of the Institute of Europe, 314, 78-86.

Ponomarev, N. (2019). Electoral populism: in anticipation of the Russian edition. PRISP. 15.02.2019. Retrieved from http://www.prisp.ru/analitics/1788-ponomarev-elektoralnyi-populizm-kak-yavlenie-1502

Rakhmanov, A. S. (2016). Northern model of right-wing radicalism (on the example of right-wing parties and movements of Norway). Questions of history and culture of Northern countries and territories, 3(35), 76-91.

Rovinskaya, T. L. (2015). Political ambitions of European "pirates". World economy and international relations, 7, 72-84.

Shveitser, V. Ya. (2016). Eurosceptics' time? Electoral processes in the European Union (The middle of the XXI century second decade). Reports of the Institute of Europe, 335, 7-10.

Stepanov, G. V. (2017). "Alternative for Germany" - alternative for disillusioned voters? Conservative, social and liberal tendencies in the party political development of Germany and Russia: history and modernity. Reports of the international scientific seminar,229 - 235. Retrieved from http://vereinigung.ru/download/mns_2016.pdf

Zabelin, S. A., \& Vlasova, K. V. (2015). The left radicals of Greece: a breakthrough in power. Elections and election campaigns in Europe (2014-2015). Reports of the Institute of Europe, 320, 58-67.

Zaslavsky, S. E. (2005). Fundamentals of the theory of political parties. Moscow: Europe.

\section{Note}

Note 1. July 2018 saw the party changing its name to the National Rally.

\section{Copyrights}

Copyright for this article is retained by the author(s), with first publication rights granted to the journal.

This is an open-access article distributed under the terms and conditions of the Creative Commons Attribution license (http://creativecommons.org/licenses/by/4.0/). 